\title{
Permohonan Tanah Ulayat di Minangkabau Menjadi Tanah
}

\section{Hak Milik}

\author{
Siti Raga Fatmi \\ University of Jember, Indonesia \\ ragafatmi2014@gmail.com
}

\begin{abstract}
A communal land is an asset owned by customary law communities and jointly managed by members of customary law communities. Customary land in Minangkabau has been recognized in Indonesian law as mentioned in Article 3 of the Basic Agrarian Law Number 5 of 1960 (BAL) as long as it still exists and corresponding to the development. In fact, although a communal land in Minangkabau is administered collectively, the later development shows that such a communal land has been converted to the proprietary right by customary law communities due to the demand for legal recognition. BAL states that property rights are hereditary, strongest, and fulfilled rights owned by a person on a piece of land. Since there are no regulations governing the transfer of communal land to land ownership, the customary elders and regional apparatus make procedures for the transfer of communal land with certain conditions so that not everyone can submit an application for ownership of customary land into land owned.
\end{abstract}

KEYWORDS: Customary Land, Proprietary Rights, Land Registration.

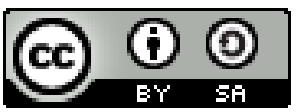

Copyright $\odot 2018$ by Author(s)

This work is licensed under a Creative Commons Attribution-ShareAlike 4.0 International License. All writings published in this journal are personal views of the authors and do not represent the views of this journal and the author's affiliated institutions.

\section{HOW TO CITE:}

Fatmi, Siti Raga. "Permohonan Tanah Ulayat di Minangkabau Menjadi Tanah Hak Milik" (2018) 5:3 Lentera Hukum 415-430.

Submitted: August 01, 2018 Revised: October 18, 2018 Accepted: December 22, 2018 


\section{PENDAHULUAN}

Berdasarkan penjelasan umum angka 2 Undang-Undang Nomor 5 Tahun 1960 tentang Peraturan Dasar Pokok-Pokok Agraria (UUPA) dijelaskan bahwa kata dikuasai tidak sama dengan dimiliki. Akan tetapi, artinya yaitu memberi wewenang kepada negara sebagai organisasi kekuasaan, untuk tingkatan yang tertinggi yaitu mengatur dan menyelenggarakan peruntukan, penggunaan, persediaan, dan pemeliharaannya, menentukan dan mengatur hak-hak yang dapat dipunyai atas (bagian dari) bumi, air dan ruang angkasa itu dan menentukan dan mengatur hubungan-hubungan hukum antara orang-orang dan perbuatan-perbuatan hukum yang mengenai bumi, air, dan ruang angkasa.

Oleh sebab itulah negara hanya sebagai penguasa saja, bukan sebagai yang memiliki. Hak milik dari tanah Indonesia berada pada rakyat Indonesia itu sendiri yang secara umum disebut sebagai hak kolektif. ${ }^{1}$ Menurut perkembangan dari sejarah negara Indonesia, tanah Indonesia pada awalnya dikuasai oleh masyarakat hukum adat yang ada diseluruh wilayah Indonesia. Pada tahun 1602, penjajah datang ke Indonesia untuk berdagang, namun lama kelamaan mereka menguasai tanah-tanah di Indonesia dengan menerapkan sistem pemerintahan kolonial. Pemerintah kolonial menerapkan dualisme hukum pertanahan yaitu berlakunya dua stelsel hukum yang berbeda pada ruang dan waktu yang sama. Dualisme tersebut adalah berlakunya hukum agraria adat untuk orang pribumi dan hukum agraria barat untuk orang Eropa, Tionghoa, dan Timur Asing. ${ }^{2}$ Selain itu juga diberlakukan asas 'domein verklaring' pada aturan Agrarische Besluit/AB yang menyatakan bahwa siapapun yang tidak dapat membuktikan bahwa suatu tanah itu sebagai miliknya, maka tanah itu akan menjadi milik negara. Pada saat itu hampir sebagian besar tanah rakyat Indonesia dimiliki oleh negara (yang dalam hal ini diatur oleh pemerintah kolonial), karena para rakyat ini tidak dapat memberikan pembuktian yang ditetapkan oleh negara yaitu pembuktian tertulis seperti sertifikat.

Walaupun hukum agraria nasional bersumber dari hukum adat, namun tetap harus tidak bertentangan dengan undang-undang atau peraturan yang lebih tinggi sebagaimana dimaksud dalam Pasal 3 UUPA yaitu dengan mengingat ketentuanketentuan dalam Pasal 1 dan 2 pelaksanaan hak-ulayat dan hak-hak yang serupa itu dari masyarakat-masyarakat hukum adat, sepanjang menurut kenyataannya masih ada, harus sedemikian rupa sehingga sesuai dengan kepentingan nasional dan negara, yang berdasarkan atas persatuan bangsa serta tidak boleh bertentangan dengan undangundang dan peraturan-peraturan lain yang lebih tinggi.

UUPA memberi kebebasan kepada warga negara Indonesia untuk memiliki penguasaan hak-hak atas tanah, salah satunya yaitu hak milik. Hak milik dapat dimohon oleh warga negara Indonesia atas tanah yang dikuasai oleh negara. Permohonan hak milik tersebut dapat dilakukan atas dasar Pasal 8 sampai dengan Pasal 16 Peraturan Menteri Agraria/Kepala BPN Nomor 9 Tahun 1999 tentang Tata Cara

1 Fifik Wiryani, Reformasi Hak Ulayat (Malang: Setara Press, 200) at 4.

2 Samun Ismaya, Pengantar Hukum Agraria (Yogyakarta: Graha Ilmu 2011) at 17. 
Pemberian Dan Pembatalan Hak Atas Tanah Negara dan Hak Pengelolaan (untuk selanjutnya disebut Permen Agraria No. 9 Tahun 1999).

Melihat kesempatan yang diberikan oleh negara terhadap tanah yang dikuasai oleh negara, beberapa masyarakat adat juga menginginkan hak milik atas tanah, namun yang menjadi permasalahan yaitu jika yang dimintai hak milik adalah tanah ulayat yang sebenarnya milik dari suatu kaum adat. Masyarakat Minangkabau merupakan suatu kelompok masyarakat hukum adat yang masih memegang teguh hukum adatnya. Dalam adat minangkabau tanah ulayat merupakan harta pusaka yang dikuasai secara komunal atau bersama-sama. Namun seiring dengan berjalannya zaman, banyak masyarakat adat Minangkabau yang kemudian melanggar ketentuan adat tersebut karena dianggap sudah tidak sesuai dengan perkembangan zaman, salah satunya mengenai pengalihan tanah ulayat menjadi tanah hak milik.

\section{TANAH ULAYAT MASYARAKAT HUKUM MINANGKABAU SETELAH LAHIRNYA UUPA}

Pengakuan terhadap hukum adat di Indonesia telah diatur dalam Pasal 18B ayat (2) UUD 1945 yang menyatakan bahwa negara mengakui dan menghormati kesatuankesatuan masyarakat hukum adat beserta hak-hak tradisionalnya sepanjang masih hidup dan sesuai dengan perkembangan masyarakat dan prinsip negara Kesatuan Republik Indonesia, yang diatur dalam undang-undang.

Dalam Pasal 5 UUPA juga dijelaskan bahwa hukum agraria yang berlaku atas bumi, air dan ruang angkasa ialah hukum adat, sepanjang tidak bertentangan dengan kepentingan nasional dan negara, yang berdasarkan atas persatuan bangsa, dengan sosialisme Indonesia serta dengan peraturan-peraturan yang tercantum dalam Undangundang ini dan dengan peraturan perundang-undangan lainnya, segala sesuatau dengan mengindahkan unsur-unsur yang bersandar pada hukum agama.

Hukum adat sebagai hukum tidak tertulis bagi masyarakat berfungsi sebagai neraca yang dapat menimbang kadar baik atau buruk, salah atau benar, patut atau tidak patut, pantas atau tidak pantas atas suatu perbuatan atau peristiwa-peristiwa dalam masyarakat. Hukum adat merupakan pilar sosioanthroplologis yang penting dalam kehidupan berbangsa dan bernegara. Hal ini membuat para legislatif, eksekutif dan yudikatif diharapkan untuk dapat menjaga dan mengambil langkah alternatif dan progresif terhadap hukum adat yang berada di Indonesia. ${ }^{3}$

\section{A. Sistem Kekerabatan}

Minangkabau merupakan salah satu kelompok etnis yang mendiami daerah Sumatera Barat yang mana merupakan suatu masyarakat hukum adat. ${ }^{4}$ Suku Minangkabau merupakan salah satu suku bangsa yang memiliki sistem kekerabatan berbeda, unik,

\footnotetext{
3 Sujitpto Raharjo, Masyarakat Hukum Adat : Inventarisasi dan Perlindungan Hak (Diterbitkan oleh Komnas HAM, MK dan Departemen Dalam Negeri, 2005) at 52.

4 Soerojo wignjodipoero, Pengantar Dan Asas-Asas Hukum Adat (Jakarta: Gunung Agung, 1994) at 197.
} 
dan langka. Sistem kekerabatan di Minangkabau disebut dengan sistem kekerabatan Matrilineal atau Matriakhat. ${ }^{5}$ Matrilineal berasal dari kata "matri" yang artinya ibu dan "lineal" yang artinya garis. Jadi matrilineal berarti garis atau hubungan keturunan yang berdasarkan kerabat ibu. Dalam segala perbuatan hukum, setiap anak mengutamakan keturunan ibu. ${ }^{6}$ Matrilineal yaitu seseorang menjadi anggota suatu masyarakat hukum adat yang bersangkutan karena ia menjadi atau menganggap dirinya sebagai keturunan dari nenek moyang perempuan atau tunggal ibu yaitu ibu asal yang menurunkan anak cucu yang perempuan itu tidak meninggalkan kerabatnya dan tidak pindah ke kerabat suaminya.

Saudara kandung disini adalah saudara perempuan yang akan melahirkan kemenakan mereka. Andaikata kemenakan yang mereka lahirkan tanpa punya tanah milik kaumnya, sama artinya kelahirannya tanpa tanah tumpah darah atau tanah air, yang akan menjadi kebanggan kelak. Oleh karena itu, tanah bukanlah semata-mata berfungsi ekonomi, melainkan lebih cenderung kepada fungsi sosial. Berdasarkan hal tersebut, A.A Navis berpendapat mungkin hal itulah yang mendorong orang Minangkabau tersebar dari kampung halamannya, baik mencari pemukiman baru ataupun merantau. Mencari pemukiman baru berarti memperoleh tanah, dan jika merantau untuk mencari rezeki yang akan dibawa pulang untuk mengurus sawah dan ladang.

\section{B. Sistem Penguasaan Tanah Ulayat dan Fungsinya \\ 1. Sistem Penguasaan Tanah Ulayat}

Pola kepemilikan tanah di Minangkabau tidaklah bersifat individual, melainkan milik komunal yaitu milik suku, kaum, dan nagari. Tanah ulayat adalah pusaka yang diwariskan turun-temurun, yang haknya berada pada perempuan, namun sebagai pemegang hak atas tanah ulayat adalah mamak kepala waris. Penguasaan dan pengelolaan tanah ulayat dimaksudkan untuk melindungi dan mempertahankan kehidupan serta keberadaan masyarakat (eksistensi kultural). Selain itu, tanah ulayat juga mengandung unsur religi, kesejarahan dan bahkan unsur magis serta bertujuan memakmurkan rakyat di dalamnya. ${ }^{7}$

Tanah ulayat adalah tanah milik komunal yang tidak boleh dan tidak dapat didaftarkan atas nama satu atau beberapa pihak saja. Penelitian Jamal et al menemukan bahwa seluruh tanah di wilayah Minangkabau, yang persis berhimpit dengan areal administratif Provinsi Sumatera Barat, merupakan "tanah ulayat" dengan prinsip kepemilikan komunal, yang penggunaan dan pendistribusian penggunaannya tunduk kepada pengaturan menurut hukum adat. ${ }^{8}$ Pendapat Singgih Praptodihardjo, tanah ulayat adalah warisan dari mereka yang mendirikan nagari, tanah tersebut bukan saja

5 Yulfian Azrial, Budaya Alam Minangkabau (Padang. Angkasa Raya, 2003) at 5.

6 Yaswirman, Hukum Keluarga Adat Dan Islam (Analisis Sejarah, Karakteristik, Dan Prospeknya Dalam Masyarakat Matrilineal Minangkabau) (Padang:Universitas Andalas, 2006) at 17.

Ibid. at 151-152.

8 Erizal Jamal et al, Struktur dan Dinamika Penguasaan Lahan pada Komunitas Lokal (Bogor: Laporan Penelitian PSE, 2001) at 526. 
kepunyaan umat yang hidup sekarang tetapi menjadi hak generasi yang akan datang, yang hidup kelak dikemudian hari.

Hak ulayat merupakan hak tertinggi di Minangkabau yang terpegang dalam tangan penghulu, ${ }^{9}$ nagari, suku, kaum atau beberapa nagari. Tanah ulayat diwarisi secara turun menurun, yang diwarisi dari nenek moyang ke generasi berikutnya dalam keadaan utuh, tidak terbagi-bagi. Sebagaimana dalam fatwa adat menyatakan bahwa ${ }^{10}$ birik-birik tabang ka sawah (Birik-birik terbang kesawah), dari sawah tabang ka halaman (dari sawah terbang ke halaman), basuo ditanah bato (bertemu ditanah bata), dari niniak turun kamamak (dari ninik turun ke mamak), dari mamak turuk ka kamanakan (dari mamak terun kemanakan), patah tumbuah hilang baganti (patah tumbuh hilang berganti) dan pusako baitu juo (pusaka begitu juga).

Ketentuan dari Peraturan Daerah Sumatera Barat Nomor 2 Tahun 2007 tentang Pokok-Pokok Pemerintahan Nagari, Pasal 1 angka 7 menerangkan bahwa nagari adalah kesatuan masyarakat hukum adat yang memiliki batas-batas wilayah tertentu, dan berwenang untuk mengatur dan mengurus kepentingan masyarakat setempat berdasarkan filosofi adat Minangkabau (Adat Basandi Syarak, syarak Basandi Kitabullah) dan atau berdasarkan asal usul dan adat istiadat setempat dalam wilayah Provinsi Sumatera Barat.

Setiap nagari di Sumatera Barat mempunyai ulayat dengan batas batas sesuai situasi alam sekitarnya, seperti puncak bukit atau sungai. Luas wilayah nagari tidaklah sama, tergantung pada kehadiran nagari yang menjadi tetangganya. Jika tidak ada yang menjadi tetangganya, maka luasnya ditentukan batas kemampuan perjalanan seseorang, mungkin sampai dipuncak bukit, tebing yang curam, sungai yang airnya deras atau hutan lebat yang tidak dapat ditembus. Wilayah yang tidak dapat ditembus itu disebut hutan lareh ( hutan lelas ), yang artinya hutan lepas yang tidak ada penghuninya. ${ }^{11}$

Menurut A.A Navis dalam satu nagari ada dua jenis ulayat yaitu: ulayat nagari dan ulayat kaum. Ulayat nagari berupa hutan yang jadi cagar alam dan tanah cadangan nagari, yang disebut hutan tinggi. Ulayat ini berada dibawah kekuasaan penghulu andiko, yang juga disebut penghulu keempat suku. Sedangkan ulayat kaum adalah tanah yang dapat dimanfaatkan tetapi belum diolah penduduk, yang disebut hutan rendah. Ulayat ini dibawah kekuasaan penghulu suku yang jadi puncak atau Tuannya. ${ }^{12}$

Sasaran utama pemanfaatan tanah ulayat adalah untuk meningkatkan kesejahteraan dan kemakmuran masyarakat adat. Pemanfaatan tanah ulayat dilakukan dengan prinsip saling menguntungkan dan berbagi resiko dengan kaedah " adat diisi limbago dituang" melalui musyawarah mufakat.

9 Berdasarkan Pasal l angka 12 PERDA Sumatera Barat No. 16 Tahun 2008 penghulu adalah pemimpin dalam suku ataupun kaum, ia adalah pemegang hak ulayat atas sako (gelar kebesaran pemimpin) dan pusako (harta pusaka berupa tanah ulayat dan harta benda).

10 M. Narson, Dasar Falsafah Adat Minagkabau. (Jakarta: Bulan Bintang, 1971) at 41.

11 A.A Navis, Alam Takambang jadi Guru (Jakarta: PT Grafiti Pers, 1986) at 151.

12 Ibid, at 152 
Tanah ulayat di Minangkabau disebut sebagai harta pusaka. Sistem pemilikan harta atau cara seseorang mendapatkan harta tersebut yaitu Pusako (pusaka), Tambilang Basi (tembilang besi), yaitu memperoleh harta dengan usaha sendiri, misalnya manaruko. Manaruko yaitu membuka lahan yang belum ada pemiliknya atau hutan yang belum mempunyai pemilik, hal ini merupakan salah satu usaha dan kebiasaan nenek moyang orang Minangkabau pada zaman dahulu, Tambilang Ameh (tembilang emas) yaitu memiliki harta dengan cara membeli dan Hibah (pemberian).

Tanah ulayat di Minangkabau diatur pimpinan adat yang disebut ampek jinih, penghulu manti, dubalang dan malin yang berkedudukan di kaum dan atau di suku dan atau di nagari. Orang ampek jinih itu ibarat empat badan satu nyawa. Artinya, sistem kepemimpinannya satu atap atau satu kotak. Rusak satu rusak yang lainnya.

\section{Fungsi Tanah Ulayat}

Tanah ulayat di Minangkabau dimanfaatkan untuk kesejahteraan anak kemenakan atau sebagai tanah cadangan bagi anak kemenakan yang makin bertambah di kemudian hari. Dimana mereka dapat mempergunakan tanah tersebut untuk keperluan membangun rumah tempat tinggal, tempat berdagang seperti membuat toko atau rumah dan toko dan untuk bercocok tanam. Menurut pendapat Prof. Van Vollenhoven bahwa fungsi dari ulayat atas tanah ada dua fungsi. ${ }^{13}$ Pertama, fungsi ke dalam daerahdaerah persekutuan hukum dapat penjelmaannya antara lain anggota-anggota persekutuan hukum mempunyai hak-hak tertentu atas objek hak ulayat yaitu 1) Hak atas tanah adalah hak untuk membuka tanah, hak untuk memungut hasil, hak untuk mendirikan tempat tinggal, hak mengembala; 2) Hak atas air adalah hak untuk memakai air, hak untuk menangkap ikan dan Iain-lain dan 3) Hak atas hutan adalah hak berburu, hak-hak untuk mengambil hutan dan sebagainya. Kemudian, kembalinya hak ulayat atas tanah-tanah dalam hal pemiliknya pergi tak tentu rimbanya, meninggal tanpa waris atau tanda-tanda membuka tanah telah punah. Persekutuan menyediakan tanah untuk keperluan persekutuan umpamanya tanah perkuburan, jembatan dan lainnya. Bantuan kepada persekutuan dalam hal transaksi-transaksi tanah dalam hal ini dapat dikatakan kepada persekutuan bertindak sebagai pengatur.

Kedua, fungsi ke luar daerah-daerah persekutuan hukum tampak penjelmaannya antara lain melarang untuk membeli atau menerima atas gadai tanah (terutama dimana tanah ulayat itu masih kuat), untuk mendapat hak memungut hasil atas tanah memerlukan izin serta membayar retribusi dan tanggung jawab persekutuan atas reaksi adat, dalam hal-hal terjadinya suatu delik dalam wilayahnya yang sipembuatnya tidak diketahui. Dapat dilihat fungsi hak atas tanah menurut Pasal 6 UUPA, yang menerangkan bahwa: "semua hak atas tanah mempunyai fungsi sosial", sama atau sesuai dengan arti fungsi dari tanah ulayat.

Fungsi masyarakat hukum adat menurut hukum ulayat adalah sebagai badan yang menguasai dan mengatur penyediaan, peruntukan, penggunaan tanah bagi

13 Van Vollenhoven dalam Syahmunir AM, Eksitensi Tanah Ulayat dalam Perundangundangan di Indonesia (Padang : Pusat Pengkajian Islam dan Minagkabau (PPIM), 2000) at 126. 
kesejahteraan anggota warga masyarakat. Masyarakat hukum adat melalui para pejabat adat, berperan sebagai pemelihara dan penjaga yang menjamin keamanan serta kenyamanan penggunaan tanah maupun menikmati hasilnya.

Berdasarkan maksud dan tujuan pencananggan tanah ulayat sebagaimana tersebut diatas, maka ajaran adat Minangkabau menetapkan bahwa tanah ulayat tidak boleh diperjual belikan dan atau digadaikan kepada orang lain. Komunitas masyarakat hukum adat dapat memetik hasil atas tanah ulayat tersebut. Hal ini sesuai dengan falsafah yang menyatakan "ainyo buliah diminum, buahnyo buliah dimakan, dijual indak dimakan bali, digadai indak dimakan sando".

Namun demikian dalam beberapa hal tanah ulayat itu boleh digadaikan sepanjang tidak menyimpang dari "pusakosalingka suku". Maksudnya adalah bahwa tanah ulayat boleh digadaikan kepada anggota suku dengan memenuhi persyaratan tertentu. Pertama, Gadih gadang indak balaki (gadis yang sudah dewasa belum bersuami) atau rando dapek malu (janda yang mendapat malu). Gadai dapat dilakukan untuk mengawinkan kemenakan yang telah dewasa atau janda. Kedua, Rumah gadang katirisan (rumah besar bocor atau rusak). Gadai dapat dilakukan dengan maksud untuk memperbaki rumah besar yang bersangkutan. Ketiga, Mambangkik batang tarandam (membangkit batang terendam). Gadai dapat dilakukan dengan maksud untuk menghidupkan kembali gelar Penghulu yang telah lama tidak dipakai. Keempat, Mayiek tabujua di tangah runah (mayat terbujur diatas rumah belum dimakamkan). Gadai dapat dilakukan untuk menyelenggarakan pemakaman anggota kaum yang meninggal.

Gambaran diatas dapat terlihat bahwa kepemilikan dan penguasaan tanah ulayat di Minangkabau bersifat "kolektif dan sekaligus tidak mengenal kepemilikan yang bersifat mutlak. Konsekuensi logisnya adalah tidak mungkin ada pengalihan hak atas tanah dari satu person kepada person lain, bahkan pengalihan hak dari satu kaum kepada kaum yang lain. Hal ini didasarkan atas kenyataan, bahwa tanah merupakan wujud dari ikatan lahir batinsuatu komunitas masyarakat hukum adat dan sekaligus sebagai asset bersama suatu komunitas masyarakat hukum adat di Minangkabau. Jika suatu kaum tidak mempunyai tanah ulayat lagi, maka runtuh atau hilanglah keutuhannya, karena tanah berfungsi sebagai pengikat (batin) antara sesama komunitas masyarakat hukum adat. Dengan kata lain tanah ulayat itu dipertahankan oleh masyarakat hukum adat Minangkabau tidak lain berdasarkan sifat hubungan yang "religio-magis-kosmis", sehingga mempertahankan pengusaan tanah ulayat adalah karena "marwah-nya". 14

Dalam hal pemanfatan tanah ulayat oleh pihak luar adalah prinsip keseimbangan dan keadilan, sebagai mana falsafah adat menyatakan "urang mandapek, awak indak kailangan" (orang mendapat, kita tidak kehilangan). Selain dari pemanfaatan tanah ulayat akan terkena "Sumpah Pasatiran", yaitu "kaateh indak bapucuak, kabawah indak baurek, ditangah digiriak kumbang (keatas tak berpucuk, kebawah tak berurat/berakar dan

14 Menurut Narullah yang dimaksud dengan "marwah" itu adalah norma-norma dan nilai nilai yang paling esensil dari hukum adat itu sendiri. 
ditengah digiri/dilobang kumbang)" ${ }^{\prime 15}$. Sehingga orang yang kena sumpah pasatiran ini hidupnya merana sepanjang masa. Sejalan dengan konsep tanah ulayat yang tidak boleh diperjual belikan dan digadaikan, maka setelah pemanfatan tanah ulayat dilakukan tanah tersebut kembali kepada pemiliknya.

\section{Macam-Macam Tanah Ulayat}

Menurut Pasal 1 Peraturan Daerah Sumatera Barat Nomor 16 Tahun 2008 tentang Tanah Ulayat dan Pemanfaatannya, tanah ulayat terdapat empat macam tanah ulayat, yaitu: tanah ulayat nagari, tanah ulayat suku, tanah ulayat kaum, dan tanah ulayat rajo. Pertama, adalah Tanah Ulayat Nagari, sebagaimana Pasal 1 angka 8 Peraturan Daerah Sumatera Barat Nomor 16 Tahun 2008 tentang Tanah Ulayat Dan Pemanfaatannya, tanah ulayat nagari adalah tanah ulayat beserta sumber daya alam yang ada diatas dan didalamnya merupakan hak penguasaan oleh ninik mamak Kerapatan Adat Nagari (KAN) dan dimanfaatkan sebesar-besarnya untuk kepentingan masyarakat nagari, sedangkan pemerintahan nagari bertindak sebagai pihak yang mengatur untuk pemanfaatannya. Masyarakat terikat pada hutan jauh baulangi hutan dakek bakundanoi (hutan jauh yang dilihat pada saat - saat tertentu untuk membuktikan kepemilikan, hutan dekat yang dipelihara) tanah yang pernah diolah (dikerjakan) tetapi ditinggalkan kembali (verlaten ground) oleh suku atau anggota suku dalam suatu nagari. Tanah yang selalu dihuni atau diolah terus menerus oleh anggota suku (baik dalam bentuk sawah, ladangatau arcal pemukiman), tanah yang digunakan sebagai pasar atau termpat bermusyawarah.

Kedua, adalah Tanah Ulayat Suku, sebagaimana Pasal 1 angka 9 Peraturan Daerah Sumatera Barat Nomor 16 Tahun 2008 tentang Tanah Ulayat Dan Pemanfaatannya, tanah ulayat suku adalah hak milik atas sebidang tanah berserta sumber daya alam yang berada diatasnya dan didalamnya merupakan hak milik kolektif semua anggota suku tertentu yang penguasaan dan pemanfaatannya diatur oleh penghulu-penghulu suku. Ketiga, yaitu Tanah Ulayat Kaum, sebagaimana Pasal 1 angka 10 Peraturan Daerah Sumatera Barat Nomor 16 Tahun 2008 tentang Tanah Ulayat Dan Pemanfaatannya, tanah ulayat kaum adalah hak milik atas sebidang tanah beserta sumber daya alam yang ada diatas dan didalamnya merupakan hak milik semua anggota kaum yang terdiri dari jurai/paruik yang penguasaan dan pemanfaatannya diatur oleh mamak jurai/mamak kepala waris.

Keempat, yaitu Tanah Ulayat Rajo, sebagaimana dalam Pasal 1 angka 11 Peraturan Daerah Sumatera Barat Nomor 16 Tahun 2008 tentang Tanah Ulayat Dan Pemanfaatannya, tanah ulayat rajo adalah hak milik atas sebidang tanah beserta sumber daya alam yang ada diatas dan didalamnya yang penguasaan dan pemanfaatannya diatur oleh laki-laki tertua dari garis keturunan ibu yang saat ini masih hidup disebagian Nagari di Propinsi Sumatra Barat. Menurut pendapat Narullah Parpatiah Nan Tuo, dikatakan bahwa tanah ulayat rajo ada karena tanah ulayat yang dikuasai

15 B. Nurdin Yakub, hukum kekerabatan minagkabau, (Jakarta: CV Pustaka Indonesia, 1994) at 13. 
oleh beberapa nagari. Penguasaan oleh nagari-nagari dapat dilakukan dengan manaruko atau membuka lahan baru.

\section{Eksistensi Tanah Ulayat}

UUPA berpangkal pada pengakuan hak ulayat dalam huum tanah yang baru, tetapi pelaksanaannya dibatasi. Jika pemerintah akan memberikan sesuatu hak atas tanah, maka sebagai tanda pengakuan itu masyarakat hukum adat yang bersangkutan akan didengar pendapatnya dan akan diberi "recognitie", yang memang ia berhak menerimanya sebagai pemegang hak ulayat. Dari contoh ini dapat diketahui pula bahwa pendirian UUPA mengenai hubungan antara hak ulayat dengan tanah negara. Menurut Pasal 28 ayat (1) yang dapat diberikan dengan hak guna usaha ialah tanahtanah yang "dikuasai lansung oleh negara". Tanah-tanah yang demikian itu disebut "tanah negara".

UUPA dan hukum tanah nasional tidak menghapus hak ulayat, tetapi juga tidak akan mengaturnya. Mengatur hak ulayat dapat berakibat melanggengkan atau melestarikan eksistensinya. Padahal perkembangan masyarakat menunjukkan kecenderungan akan hapusnya hak ulayat tersebut melalui proses alamiah. Yaitu dengan menjadi kuatnya hak-hak perseorangan dalam masyarakat hukum adat yang bersangkutan. Kecenderungan tersebut tampak pada perkembangan tanah-tanah kaum di Minangkabau, yang dimintakan pendaftaran sebagai tanah milik-bersama. Setelah didaftar sebagai milik-bersama, maka diadakan pemecahan menjadi tanah-tanah hak milik para anggota kaum masing-masing. Padahal hak penguasaan oleh para anggota kaum menurut hukum adat bukan hak milik, melainkan ganggam bauntuak, yang dalam hukum tanah nasional dikonversi menjadi hak pakai. ${ }^{16}$

Hak ulayat diakui eksistensinya bagi masyarakat hukum adat tertentu, sepanjang menurut kenyataanya masih ada. Masih adanya hak ulayat pada suatu masyarakat hukum adat tertentu, antara lain dapat diketahui dari kegiatan sehari-hari kepala adat dan para tetua adat dalam kenyataannya, sebagai pengemban tugas kewenangan mengatur penguasaan dan memimpin penggunaan tanah ulayat, yang merupakan tanah bersama para warga masyarakat hukum adat, yang bersangkutan. Selain diakui, pelaksanaannya dibatasi, dalam arti harus sedemikian rupa sehingga sesuai kepentingan nasional dan negara yang berdasarkan atas persatuan bangsa serta tidak boleh bertentangan dengan undang-undang dan peraturan-peraturan yang lebih tinggi. Demikian dinyatakan dalam Penjelasan Umum UUPA. Merupakan suatu kenyataan, bahwa jika dalam usaha memperoleh sebagian tanah ulayat untuk keperluan pembangunan, dilakukan pendekatan pada para penguasa adat serta warga masyarakat hukum adat yang bersangkutan menurut adat-istiadat setempat, yang hakikatnya mengandung pengakuan adanya hak ulayat itu. Tetapi instansi pemerintah atau penguasaha yang berusaha memperoleh tanah ulayat semata-mata berdasarkan surat

16 Budi Harsono, Hukum Agraria Indonesia : Sejarah Pembentukan Undang-Undang Pokok Agraria, Isi dan Pelaksanaannya (Jakarta: Djambatan. 1997) at 186. 
keputusan pejabat atau instansi pemerintah yang diberikan kepadanya, pasti akan menghadapi kesulitan dalam pelaksanaannya.

Hak ulayat yang pada kenyataanya tidak ada lagi, tidak akan dihidupkan kembali. Juga tidak akan diciptakan hak ulayat baru. Dalam rangka hukum tanah nasional tugas kewenangan yang merupakan unsur hak ulayat, telah menjadi tugas kewenangan negara Republik Indonesia, sebagai kuasa dan petugas bangsa. Pada kenyataannya kekuatan hak ulayat cenderung berkurang, dengan makin menjadi kuatnya hak pribadi para warga atau anggota masyarakat hukum adat yang bersangkutan atas bagianbagian tanah ulayat yang dikuasainya. Oleh karena itu hak ulayat tidak akan diatur dan UUPA juga tidak memerintahkan untuk diatur, karena pengaturan hak tersebut akan berakibat melansungkan keberadaannya.

Secara umum, ada empat syarat yuridis terkait dengan eksistensi hukum adat beserta komentar sebagaimana diuraikan oleh Sadjipto Rahardjo adalah sebagai berikut. ${ }^{17}$ Pertama, "Sepanjang masih hidup". Maksud dari sepanjang masih hidup ini tidak semata-mata melakukan pengamatan dari luar, melainkan juga dengan menyelami perasaan masyarakat setempat (pendekatan partisipatif). Kedua, "Sesuai dengan perkembangan masyarakat”. Hal ini mengandung resiko untuk memaksakan (imposing) kepentingan umum atas nama "perkembangan masyarakat", sehingga tidak memberi peluang untuk membiarkan dinamika masyarakat setempat berproses sendiri secara bebas. Ketiga, "Sesuai dengan prinsip NKRI". Kelemahan dari paradigma ini adalah dengan melihat NKRI dan masyarakat adat sebagai dua antitas yang berbeda dan berhadap-hadapan. Keempat, "Diatur dalam undang-undang”. Indonesia merupakan negara hukum namun apabila hukum selalu ingin mengatur ranahnya sendiri dan merasa cakap untuk itu telah gagal (apabila tidak melibatkan fenomena sosial lainnya).

Pemanfaatan tanah ulayat di Minangkabau, sekarang ini sudah dapat dimanfaatkan oleh orang lain, bahkan oleh orang atau lembaga asing, asal saja "adat diisi limbago dituang" ,maksudnya yaitu dalam hal pemanfaatan oleh orang luar harus melalui proses musyawarah dan mufakat. Pemanfaatan tanah ulayat tidaklah berarti memilikinya, oleh karena itu dikenal pepatah adat "kabau pai kubangan tingga" artinya apabila pemanfaatan tanah ulayat sudah selesai atau tidak dipergunakan lagi akan kembali kepada pemilik ulayat. Seluruh peraturan adat itu haruslah diperhatikan dalam setiap pemanfaaatan tanah ulayat itu apakah untuk kepentingan masyarakat dalam persekutuan hukum adat atau untuk warga atau persekutuan di luar persekutuan.

Pemanfaatan tanah bagi warga luar persekutuan tidaklah mudah, sangat diperlukan musyawarah dan mufakat, karena telah berurat dan berakar pada masyarakat hukum adat, dan kalau diikuti dengan baik untuk pemanfaatan tanah ulayat akan memenimalkan kasus-kasus sengketa tanah ulayat yang ada dan yang akan ada. Dalam melaksanakan musyawarah dan mufakat haruslah dilakukan dengan mendudukan hak dan kewajiban secara seimbang antara kedua belah pihak dan tanpa

17 Ibid. at 54 
tekanan oleh siapapun, apabila ini tidak dilakukan dengan baik, maka akan memunculkan kasus sengketa disebabkan ketidak puasan dari masyarakat hukum adat.

Ketentuan dalam adat Minangkabau melarang memindahtangankan tanah ulayat kaum, kecuali dalam keadaan mendesak, sebagaimana fatwa adat mengatakan "dijua indak dimakan budi, digadai indak dimakan sando". Apabila pemindahtanganan tersebut mesti terjadi, maka harus atas kepentingan bersama dan mendapat persetujuan dari seluruh anggota kaum dan izin dari mamak kepala waris serta diketahui oleh pucuk pimpinan adat. Terjadinya pemindahtangan hak ulayat kaum untuk selamanya (dijual) karena memang tidak dapat dipungkiri bahwa adat Minangkabau saat ini tengah mengalami perubahan yang secara berangsur-angsur dari sifat komunal mengarah kepada sifat individual terutama dalam kepemilikan tanah ulayat kaum. Hal ini lebih cenderung terjadi di pusat-pusat perkotaan atau daerah-daerah yang dekat dengan pusat kota. Seperti masyarakat nagari yang berdampingan dengan kota Bukititnggi yang sudah mulai mengarah kepada kehidupan individual, sehingga pemindahtangan tanah ulayat kaum tidak merupakan yang sakral lagi, tetapi telah berangsur-angsur merupakan hal yang biasa bagi masyarakat. Namun bukan berarti tidak semudah memindahtangankan tanah yang merupakan hasil pencaharian, akan tetapi masih memerlukan atau mendapatkan persetujuan dari seluruh anggota kaum, karena tanah ini merupakan kepunyaan bersama anggota kaum.

Pemindahtanganan tanah ulayat hanya bersifat sementara karena tanah di Minangkabau merupakan kekayaan yang dimiliki oleh sebuah kaum yang harus dijaga keberadaannya. Hal ini juga kerana adanya aturan adat yang menyatakan bahwa tidak membenarkan terjadinya alih kepemilikan tanah keluar kerabat matrilineal. Sedangkan pemindahtanganan tanah ulayat kaum untuk selamanya biasanya dilakukan oleh kaum yang hampir punah dan diupayakan kepada orang yang terdekat terutama orang masih dalam persukuan yang sama. Namun berdasarkan Keputusan Mahkamah Agung Nomor: 1029K/Sip/1975 menyatakan bahwa pemindahtanganan tanah ulayat kaum yang hampir punah dapat diberikan kepada siapa saja yang dikehendaki oleh kaum punah tersebut.

\section{PERMOHONAN TANAH ULAYAT MENJADI TANAH HAK MILIK}

Dalam Pasal 22 UUPA dijelaskan bahwa terjadinya hak milik menurut hukum adat diatur dengan peraturan pemerintah. Sebagaimana telah diketahui bahwa sampai sekarang peraturan pemerintah yang dimaksud dalam pasal tersebut masih belum dibentuk juga. Hal ini mengakibatkan permohonan tanah ulayat atau tanah adat menjadi tanah hak milik secara hukum masih belum memiliki regulasi yang jelas seperti permohonan tanah negara menjadi tanah hak milik.

Menurut ajaran adat Minangkabau, pengertian tanah dan ulayat dipisahkan, pemisahan ini dilatar belakangi dengan dianutnya asas terpisah horizontal yang dalam bahasa Belanda disebut Horizontale Spitlsing. Yang dimaksud dengan asas terpisah horizontal adalah terpisahnya antara tanah dan ulayat. Masyarakat adat hanya dapat 
menikmati hasil ulayat dan hak mendirikan banguna diatas tanah tersebut. Apabila pemilik bangunan ingin menjual bangunannya tidak serta merta dengan tanah ulayat. Adat menfatwakan tanah ulayat sebagai ""ayia nyo buliah diminum, buahnyo buliah dimakan, dijual indak dimakan bali, digadai indak dimakan sando" artinya yaitu "airnya yang boleh diminum, buahnya yang boleh dimakan, tanahnya tetap tinggal air dan buah ialah ulayat". Konsekuensi dari asas ini adalah bahwa tanah ulayat di Minangkabau tidak boleh dilepaskan kepada orang lain.

Hukum Adat Minangkabau mempunyai hak dari tanah ulayat atau yang disebut harta pusaka tinggi, tidak boleh diperjual belikan, sesuai dengan pameo masyarakat Minangkabau, "Dijua ndak dimakan bali, digadai tak dimakan sando" artinya dijual tak dimakan beli, digadai tak dimakan sando (sandera). Ajaran adat Minangkabau menetapkan bahwa tanah ulayat tidak boleh diperjual belikan dan atau digadaikan kepada orang lain. Komunitas masyarakat hukum adat dapat memetik hasil atas tanah ulayat tersebut.

Namun demikian dalam beberapa hal tanah ulayat itu boleh digadaikan sepanjang tidak menyimpang dari "pusako lingka suku". Maksudnya adalah bahwa tanah ulayat boleh digadaikan kepada anggota suku dengan memenuhi persyaratan tertentu. ${ }^{18}$ Pertama, Gadih gadang indak balaki (gadis yang sudah dewasa belum bersuami) atau rando dapek malu (janda yang mendapat malu). Gadai dapat dilakukan untuk mengawinkan kemenakan yang telah dewasa atau janda. Kedua, Rumah gadang katirisan (rumah besar bocor atau rusak). Gadai dapat dilakukan dengan maksud untuk memperbaki rumah besar yang bersangkutan. Ketiga, Mambangkik batang tarandam (membangkit batang terendam). Gadai dapat dilakukan dengan maksud untuk menghidupkan kembali gelar Penghulu yang telah lama tidak dipakai. Keempat, Mayiek tabujua di tangah runah (mayat terbujur diatas rumah belum dimakamkan). Gadai dapat dilakukan untuk menyelenggarakan pemakaman anggota kaum yang meninggal.

Tanah ulayat suku dan tanah ulayat kaum merupakan hak milik kolektif anggota suatu suku atau kaum. Sedangkan tanah ulayat rajo merupakan tanah ulayat yang penguasaan dan pemanfaatannya diatur oleh laki-laki tertua dari dari garis keturunan ibu. Tanah Ulayat Nagari di bawah pengawasan penghulu-penghulu yang bernaung dalam kerapatan nagari. Tanah ulayat nagari adalah milik bersamarakyat dalam nagari itu. Tanah ulayat nagari dapat berupa hutan-hutan, semak belukar maupun tanahtanah yang berada dalam lingkup dan pengelolahan nagari. Nagari merupakan gabungan dari beberapa koto, yang mempunyai suku serta menempati suatu wilayah tertentu. Pada umumnya di dalam suatu nagari dijumpai sedikitnya empat buah suku. Sebuah nagari dipimpin oleh seorang kepala nagari. Penggunaan tanah ulayat nagari, digunakan untuk kepentingan-kepentingan yang bersifat umum, seperti pembangunan mesjid, pembuatan balai adat, dan untuk pasar atau kepentingan lainnya yang dapat dimanfaatkan untuk kepentingan bersama. Kepemilikan tanah ulayat nagari tidak dapat diubah, kecuali atas kesepakatyan seluruh wakil suku atau kaum yang ada dalam

18 Yulfian Azrial, supra note 1 at 43-44 
nagari itu. Karena berkembangnya anak kemenakan, kebiasaan tanah ulayat nagari itu diturunkan derajatnya menjadi tanah ulayat suku atau tanah ulayat kaum.

Tanah ulayat kaum, adalah tanah-tanah yang dikelola oleh kaum secara bersama. Kaum adalah gabungan dari pada paruik (seibu) yang berasal dari satu nenek. Tanah ulayat kaum merupakan harta pusaka tinggi yang dimanfaatkan untuk kesejahteraan anak kemenakan, terutama untuk memenuhi ekonominya. Tanah ulayat kaum yang dimiliki secaral komunal itu merupakan harta yang diberikan haknya kepada anggota kaum untuk memungut hasilnya, sedangkan hak milik atas nama kaum tersebut. Harta ini jika digadaikan harus mendapat persetujuan dari kepala kaum dan seluruh anggota kaum lainnya.

Pengawasan tanah ulayat kaum atau harta pusaka tinggi ini, merupakan tugas dari kepala kaum yang disebut tungganai (mamak rumah yang dituakan) dalam jurai dan dihormati seperti yang diungkapkan dalam pepatah adat didahulukan salangkah, ditinggikan sarantiang (didahulukan selangkah dan ditinggikan seranting) oleh anggota kaumnya. Disamping dibebani dengan kewajiban-kewajiban terhadap anak kemenakannya, maka penghulu (mamak adat) juga diberi hak untuk memperoleh sawah kegadangan (sawah kebesaran) milik kaumnya. Disamping mempergunakan tanah ulayat kaum, ada juga masyarakat menggunakan tanah ulayat suku dan tanah ulayat nagari. Apabila pemakaiannya bersifat produktif seperti untuk dijual hasilnya maka di sini berlaku ketentuan adat yaitu : karimbo babunggo kayu, kasawah babunggo ampiang, kalauik babunggo karang (kerimba berbungga kayu, kesawah berbungga amping, kelaut berbungga karang). Dengan arti kata harus dikeluarkan sebagian hasilnya untuk kepentingan suku atau nagari. Tetapi tanah ulayat kaum bisa saja dimiliki oleh nagari apabila diperlukan untuk kepentingan suku atau nagari.

Sesuai dengan perkembangan zaman dan bertambahnya jumlah penduduk serta kaum kerabat. Sehingga hidup dengan mengandalkan hasil ulayat tidak memungkinkan lagi bagi masyarakat kaum adat karena tanah yang dimiliki tidak mengalami peningkatan, sedangkan jumlah kerabat semakin berkembang. Hal ini menyebabkan adanya keinginan yang bertolak belakang dari anggota kaum yaitu sebagian sekelompok menginginkan tetap berpegang teguh pada adat dengan tidak membagibagi tanah ulayat tapi mencari alternatif lain dalam pemecahannya seperti pergi merantau atau berdagang, sedangkan sebahagian lagi menginginkan pembagian terhadap tanah ulayat yang ada dan akhirnya tanah ulayat itu bisa habis atau hilang. Sedangkan tanah ulayat yang belum dibagi diperuntukkan dinyatakan sebagai tanah cadangan bagi anak kemenakan dikemudian hari. Tanah ulayat suku dan tanah ulayat nagari memiliki hubungan berjenjang dan pencadangan. Bila tanah ulayat suatu kaum habis, maka tanah ulayatnya menjadi tanah ulayat suku. Bila suatu tanah ulayat suku habis maka tanah ulayatnya beralih menjadi tanah ulayat nagari. Sehingga tanah ulayat tidak akan habis. Hal ini sesuai dengan pepatah yang menyatakan bahwa tanah ulayat itu bersifat samporono (sempurna) habis. Sementara tanah ulayat rajo, sudah tidak diketemukan lagi pada saat ini, karena sudah menjadi tanah cagar budaya yang pengelolaannya dilakukan oleh pemerintah daerah. 
Maka dari itulah, seseuai dengan perkembangan zaman maka tanah ulayat kaum kemudian dapat dijadikan sebagai tanah hak milik karena penguasaanya yang lebih sempit yaitu dikuasai oleh jurai atau keluarga, maka potensi untuk bisa dijadikan sebagai tanah hak milik lebih besar dibandingkan dengan tanah-tanah yang dikuasai oleh nagar, suku maupun oleh penghulu atau rajo. Sebagaimana telah dijelaskan diatas, bahwa regulasi mengenai permohonan tanah ulayat menjadi tanah hak milik memang belum ada, namun secara adat telah diatur sedemikian rupa dengan prosedur tersendiri.

Pertama, prosedur pada internal kaum. Dalam mengalihkan hak atas tanah ulayat ada internal kaum maka dilakukan sebagai berikut, diantaranya a) anggota kaum melakukan musyawarah untuk mufakat. Di dalam muyawarah mufakat oleh seluruh anggota kaum atau yang mewakilinya dimana yang memimpin rapat tersebut adalah mamak kepala waris. Dalam rapat ini diputuskanlah apakah tanah tersebut dapat di jual atau tidak. Dalam mengambil keputusan ini harus mempunyai satu kesepakatan bulat, dimana apabila seorang saja tidak setuju untuk menjualnya maka penjualan atas tanah tersebut tidak dapat dilakukan; b) Melakukan pembagian atau memutuskan bagian mana yang akan dialihkan (dijual). Dalam hal ini setelah diputuskan oleh mamak kepala waris yang mana telah mendapat persetujuan dari anggota kaum untuk mengalihkan (menjual) sebahagian dari tanah ulayat tersebut, maka ditentukanlah pembagiaan atas tanah ulayat tersebut yang mana untuk di jual. Dalam memutuskan bagian tanah yang akan dialihkan (dijual) di putuskan sama dalam rapat tersebut dan juga dalam memutuskan tersebut harus dengan keputusan bulat atau keseluruhan rapat menyetujuinya; c) Hasil rapat diberi tahu kepada penghulu suku. Hasil rapat anggota kaum tersebut diberi tahu kepada penghulu suku pisang aur kuning. Dimana penghulu suku disini sebagai kepala suku pisang aur kuning berfungsi untuk mengetahui bahwa ada salah satu kaumnya akan menjual tanah ulayat kaum. Mamak kepala waris akan memberi tahu kepada penghulu suku apa penyebabnya mereka menjual sebahagian dari harta kaumnya dan bagian mana yang akan di jual. Setelah mendengar semua yang di katakan oleh mamak kepala waris maka barulah penghulu suku dapat menyetujuinya. d) Hasil rapat diberi tahu pada Kerapatan Adat Nagari (KAN). Hasil dari rapat dan disetujui oleh penghulu suku maka mamak kepala waris memberi tahu kepada Kerapatan Adat Nagari supaya ketua dari Kerapatan Adat Nagari menyetujui dan mengetahui bahwa ada sebahagian dari tanah ulayat tanah kaum di nagarinya ada yang di jual.

Kedua, prosedur untuk melakukan jual beli kepada pihak pembeli. Tahapan prosedur yang dilakukan oleh kaum atau surat-surat yang harus dibuat oleh si penjual dalam hal ini anggota kaum adalah a) Ranji, ini yang dipakai adalah ranji kecil yaitu ranji anggota kaum. diamana ranji ini paling sedikit 4 (empat) tingkat golongan. Ranji yang dibuat oleh kaum dan diketahui dan ditandatangani oleh mamak kepala waris, mamak kepala suku, dan ketua Kerapatan Adat Nagari (KAN). Dalam penandatanaganan ranji tersebut diberi materai pada tandatangan mamak kepala suku; b) Surat persetujuan anggota kaum, surat persetujuan dibuat oleh mamak kepala waris, yang mana isinya adalah pembagian atau harta kaum yang akan dijual harus mendapat 
persetujuan keseluruhan dari anggota kaum, diamana disini seluruh anggota kaum harus dibuatkan namanya baik yang baru lahir, dan menandatangani. Yang menandatangani disini adalah umur 17 tahun keatas, sedangkan yang 17 tahun kebawah cukup ditulis BU (belum cukup umur). Disertai semua KTP (Kartu Tanda Penduduk); c) Surat pernyataan bahwa tanah tersebut akan diserahkan kepada siapa, di sini ditulis bahwa tanah tersebut sebelum di jual diserahkan kepada siapa (salah satu anggota kaum), diketahui dan ditandatangani oleh mamak kepala waris di beri meterai, mamak penghulu suku, Ketua Kerapatan Adat Nagari (KAN), lurah; d) Surat Keterangan, surat keterangan menerangkan bahwa letak dari tanah, dikuasai oleh sapa, diketahui dan ditandatangani oleh lurah, camat; e) Surat pernyataan pengusaan tanah, di sini menyatakan bahwa sebidang tanah yang telah dibagi yang akan di jual tersebut diatas namakan siapa, dan ditandatangani oleh bersangkutan, diketahui dan ditandatangani oleh mamak kepala waris, ninik mamak kepala suku, pemilik tanah yang berbatas dengan tanah tersebut, lurah, camat; f) Surat Pernyataan, di mana surat pernyataan ini menyatakan bahwa benar atau asli adalah tandatangan yang menguasai tanah tersebut, ditandatangani oleh yang bersangkutan memakai materai dan diketahui oleh mamak kepala waris. Dengan adanya kata sepakat dan mentaati prosedur prosedur yang telah dibuat maka kaum dalam melaksanakan peralihan hak tanah ulayat berupa jual beli akan berjalan lancer dan dikemudian harinya tidak mengakibatkan terjadi masalah atau sengketa terhadap status tanah yang telah berubah.

Setelah prosedur diatas selesai, maka hak ulayat dapat dimohonkan sebagai hak milik serta dapat didaftarkan sebagai tanah hak milik sebagaimana sesuai dengan prosedur pendaftaran tanah.

\section{KESIMPULAN}

Dari beberapa pembahasan di atas, maka dapat diambil beberapa poin penting. Pertama, eksistensi Tanah Ulayat Minangkaau dapat terlihat dari masih adanya penghormatan dari masyarakat hukum adat Minangkabau itu sendiri. Selain itu, pengakuan terhadap tanah ulayat Minangkabau juga telah diatur dalam peraturan daerah Sumatera Barat. Dengan demikian, secara tidak lansung, tanah ulayat Minangkabau secara hukum telah diakui keberadaannya. Kedua, Permohonan tanah ulayat menjadi tanah hak milik dalam hukum adat khususnya di Minangkabau memang belum diatur dalam peraturan per-undang-undangan, namun peralihan dai tanah ulayat tersebut menjadi milik perorangan atau hak milik dapat dilakukan dengan syarat-syarat tertentu yang telah disepakati bersama dengan pemuka adat dan instansi pemerintah.dalam hal ini yang berpotensi untuk bisa dijadikan sebagai tanah hak milik adalah tanah ulayat kaum.

Saran penulis, dalam rangka mempermudah terjadinya pemindahan maupun permohonan tanah ulayat menjadi tanah hak milik maka diperlukan suatu regulasi hukum baru yang mengatur bagaimana dan apa saja syarat dari pelepasan tanah ulayat tersebut agar tidak terjadi kesewenangan dalam pelepasan tersebut nantinya. Dalam hal 
ini rancangan undang-undang pengakuan dan perlindungan hak-hak masyarakat hukum adat yang akan dibahas di DPR dalam hal prosedur pengakuan status masyarakat hukum adat dan hak ulayat agar dicantumkan menyangkut pendaftaran hak ulayat yang disesuaikan dengan peta tata ruangan wilayah dan tata cara hukum adat yang berlaku setelah mendapat persetujuan dari persekutuan hukum adatnya dan jika instansi pemerintah, badan hukum dan perorangan yang bukan warga masyarakat hukum adat memerlukan tanah ulayat dari masyarakat hukum adat tertentu, maka dalam hal hak atas tanah tersebut habis masa berlakunya maka tanah tersebut kembali menjadi tanah ulayat.

\section{DAFTAR PUSTAKA}

A.A Navis, Alam Takambang jadi Guru (Jakarta: PT Grafiti Pers, 1986)

B. Nurdin Yakub, hukum kekerabatan minagkabau, (Jakarta: CV Pustaka Indonesia, 1994)

Budi Harsono, Hukum Agraria Indonesia : Sejarah Pembentukan Undang-Undang Pokok Agraria, Isi Dan Pelaksanaannya (Jakarta: Djambatan. 1997)

Erizal Jamal et al, Struktur dan Dinamika Penguasaan Lahan pada Komunitas Lokal (Bogor: Laporan Penelitian PSE, 2001)

Fifik Wiryani, Reformasi Hak Ulayat (Malang : Setara Press, 200)

M. Narson, Dasar Falsafah Adat Minagkabau. (Jakarta: Bulan Bintang, 1971)

Samun Ismaya, Pengantar Hukum Agraria (Yogyakarta: Graha Ilmu 2011)

Sujitpto Raharjo, Masyarakat Hukum Adat : Inventarisasi dan Perlindungan Hak (Diterbitkan oleh Komnas HAM , MK dan Departemen Dalam Negeri, 2005)

Soerojo wignjodipoero, Pengantar Dan Asas-Asas Hukum Adat (Jakarta: Gunung Agung, 1994)

Van Vollenhoven dalam Syahmunir AM, Eksitensi Tanah Ulayat dalam Perundangundangan di Indonesia (Padang: Pusat Pengkajian Islam dan Minagkabau (PPIM), 2000)

Yulfian Azrial, Budaya Alam Minangkabau (Padang. Angkasa Raya, 2003)

Yaswirman, Hukum Keluarga Adat Dan Islam (Analisis Sejarah, Karakteristik, Dan Prospeknya Dalam Masyarakat Matrilineal Minangkabau) (Padang:Universitas Andalas, 2006) 